\title{
PROPOSAL FOR A NEW READING OF A LINE IN THE TUŃUQUQ INSCRIPTION
}

\author{
HÜLYA YILDIZ \\ Department of Turkish Language and Literature, Anadolu University \\ Office no. C-303, Eskişehir, Turkey \\ e-mail: hkoprulu@anadolu.edu.tr
}

This paper is written in order to reread the sequence of signs $\langle\ddot{W} z c ̌ I\rangle$ and $\langle T S N\rangle$ occurring in the sentence $\langle$ ẄzčI : TSN : TWTmstgbIz〉, in the 13th line of the Tunuquq Inscription. It is proposed that

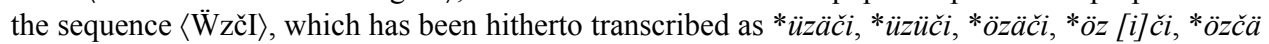

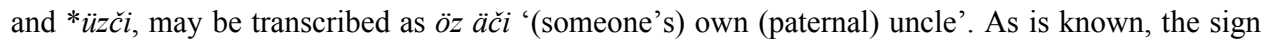
$\langle\mathrm{S}\rangle$ represents both $\check{s}$ and $s$ which have been used beside back vowels in the Tuńuquq Inscription. However, the sign $\langle\mathrm{S}\rangle$ in the $\langle\mathrm{TSN}\rangle$ sign group has been uniformly transcribed as $\check{s}$ by all previous researchers (*tašin), and they attempted to interpret that lexeme either through the meanings 'stone' or 'outside'. The present paper proposes that the $\langle$ TSN $\rangle$ sign group may also be read as atïsin 'his nephew (+acc.)'. Furthermore, the meaning 'to capture' of the Old Turkic verb tut- is particularly emphasised in the interpretation of the mentioned sentence. Finally, the whole sentence is transcribed and interpreted as öz äči atïsïn tutmïs täg biz 'We look as if (someone's) own uncle has captured his own nephew'.

Key words: Old Turkic, runic inscriptions, Orkhon inscriptions, Tuńuquq, Tońuquq, Tunyukuk, Tonyukuk.

\section{Introduction}

The subject of this paper is the Tunuquq inscription, which is one of the three most famous inscriptions from the Second Eastern Turkic Khaganate, together with the

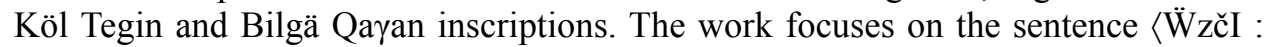
TSN : TWTmstgbIz> occurring in the 13th line of the Tunuquq inscription and provides a new reading and interpretation of this sentence.

The Tunuquq inscription is regarded as the relatively least-understood one (Tezcan 1976, p. 173) among all the Turkic runic inscriptions. The problems that are still not resolved or based on estimates and assumptions start with the first line of the 
inscription (Tezcan 2010, p. 273). This can be best exemplified by the fact that the title (or compound title) which is inscribed as $\langle\mathrm{TWn} \underline{w} \mathrm{KWK}\rangle$ in the first line has not been clearly understood or explained so far. Some other, similar problems regarding the Tunuquq inscription are as follows: (1) The disagreements over whether the first group of signs at the beginning of the 6th line of the inscription were either $\langle\mathrm{bIlsr}\rangle$ or $\langle\mathrm{b} \ddot{W} l s r\rangle$ or $\langle\mathrm{b} \ddot{W} y s r\rangle$. (2) The meaning of the lexeme $\langle\mathrm{WčwK}\rangle$ belonging to the $\langle\mathrm{YGmz}$ : tgrA: WčwKtgrtI: bIz: ఏg: rtmz $\rangle$ sentence in the 8th line and the phonemic value of the grapheme $\langle\square\rangle$ which is inscribed only in this line of the inscription have remained uncertain. (3) The problem of how to read and interpret the sequences $\langle$ WsINBWntTW in the 19th line and 〈WGRKLTDm $\rangle$ in the 25th line still cannot be solved, etc.

Some of the other distinctive characteristics of the Tunuquq inscription are the use of unusual metaphorical expressions and comparisons (Kormušin 2007, p. 263). One of these metaphorical expressions belongs to the sentence 〈ẄzčI: TSN: TWTmstgbIz〉 in the 13th line of the inscription, which includes the postposition täg 'like'. When the studies on the Tunuquq inscription are examined, it is understood that the sequence $\langle$ TWTmstgbIz $\rangle$ is transcribed as tutmiš täg biz and translated nearly the same way since Radloff's (1899) first publication. However, it is difficult to say the same for the $\langle\ddot{W} z \check{c} I\rangle$ and $\langle\mathrm{TSN}\rangle$ sign groups. In earlier studies, starting with Radloff's, the

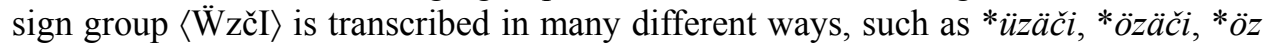
$[i] c \grave{c} i$, * $\ddot{z} z \check{c} \ddot{a}$ and $* \ddot{u} z \check{c} \dot{i}$, and the translations vary considerably depending on the transcription. The sign group $\langle\mathrm{TSN}\rangle$ is transcribed as *tašin by all the researchers, but it is analysed in different ways by them. However, those researchers did not pay attention to orthography, the grammatical structure of the sentence, the semantics of Old Turkic lexemes and the semantic frame of the context in their reading proposals. As a result, their translations became grammatically and semantically unacceptable as will be seen below.

In the following an attempt will be made to reconsider $\langle\ddot{W} z c ̌ I\rangle$ and $\langle$ TSN $\rangle$ occurring in the sentence $\langle$ ẄzčI : TSN : TWTmstgbIz〉 in the 13th line of the Tunuquq inscription and to reinterpret the whole sentence accordingly. First, the major studies on the Tunuquq inscription will be dealt with, then a proposal for a new reading will be put forward, and finally conclusions will be drawn.

\section{Major Studies on the Tuńuquq Inscription ${ }^{1}$}

There have been a number of studies, whether as a complete translation of the Tunuquq text or given as partial examples in some grammars and dictionaries (Kormušin 2007, p. 263). The complete translations of the Tuńuquq text belong to Radloff (1899), Thomsen (1922), Orkun (1936), Malov (1951), Aalto - Ramstedt - Granö (1958), Giraud (1961), Tekin (1994), Rybatzki (1997), Berta (2004), Ölmez (2012) and Aydın

\footnotetext{
${ }^{1}$ I would like to express my deepest thanks to my colleague Professor Dr. Julian Rentzsch from the Department of Turkology in Johannes Gutenberg University Mainz who kindly helped me to understand the Hungarian translation and all the German translations of the sentence.
} 
(2014). In the present section the transcriptions and translations of the above-mentioned sentence given in these studies will be evaluated from a critical point of view in chronological order.

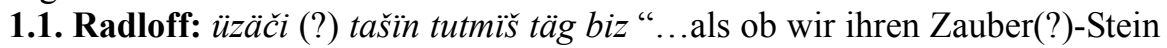
gefasst haben" $(1899$, p. 7) [...as if we have held their magic-stone].

As is seen here, Radloff, who made the first study on the Tunuquq inscription, transcribes and translates the 〈ẄzčI : TSN〉 sequence as * üzäči (?) tašin 'ihren Zauber(?)-Stein' [their magic-stone]. Accordingly, Radloff analyses the word tašïn 'ihren (Zauber)-Stein' [their (magic)-stone] as $t a \check{s}+\ddot{i}+n<\operatorname{tas}$ 'Stein' [stone] $+\ddot{i}$ (3rd person singular/plural possessive suffix) $+n$ (the accusative case after possessive). However, since there has been no such word as * ̈̈zäči 'Zauber' [magic] in Old Turkic, it is not appropriate to interpret the supposed noun phrase *üzäči (?)-tašin as 'ihren Zauber(?)-Stein' [their magic-stone].

Beside * üzäči, Radloff transcribes the sign group $\langle\ddot{W} z c ̌ I\rangle$ in a different way, as * üzüči $(1899$, p. 42). He analyses this supposed lexeme as a denominal noun from üzüt 'böser Geist' [evil spirit] (1899, pp. 41-42). Radloff states that *üzüči qualifies the lexeme taš 'Stein' [stone] and this *üzüči-stone may be a kind of amulet which protects men. However, as can be proved by the examples sï̈ïtči 'mourner' in Köl Tegin Eastern face, 4th line (Clauson 1972, p. 807b); otča 'like fire' in Köl Tegin Eastern face, 37th line (see o:t I Clauson 1972, p. 34b); ortčä 'like a conflagration' in Tuńuquq, 20th line (see ört Clauson 1972, p. 201a), the consonant cluster -tč- is already preserved in Orkhon Turkic. Thus $-t \grave{c}->*_{-} \check{c} c->*_{-} \check{c}$ - assimilation is not valid regarding this period of the Old Turkic language.

1.2. Thomsen": "Wir sind gleichsam nach dem Willen des Schicksals mit einem Stein gefangen (?)" (Thomsen 1924, p. 164, translated from Thomsen 1922) [We look as though having been captured with a stone, according to the will of fate (?)].

No transcription and transliteration of the inscription is given in this publication. According to the German translation, it is understood that Thomsen also sees the lexeme taš 'Stein' [stone] in the $\langle\mathrm{TSN}\rangle$ sign group as Radloff. But unlike Radloff, Thomsen analyses the ending $+n$ as the instrumental case suffix. This interpretation of Thomsen can be criticised since (1) the sentence is translated in the passive voice despite its being an active one; (2) 〈ய̈ZžI $\rangle$ sign group is translated as 'nach dem Willen des Schicksals' [according to the will of fate], in a rather free way.

1.3. Orkun: özäči tašïn tutmïs täg biz "Taşla tutulmuş gibi tehlikede olacağız" (1936, p. 104) [We will be in danger, as though having been captured by stone(s)].

One of the relatively early studies on the Tunuquq inscription belongs to Orkun. In this study, the sign group 〈ẄzčI〉 is transcribed as * özäči, but it is not included in the translation. On the other hand, this supposed lexeme is given in the glossary of the study under the item $\ddot{o z}$ 'self' (1936, p. 79). However, a denominal noun suffix such as *+äč $i$ does not occur in Old Turkic, consequently Orkun's reading is grammatically improbable.

As for the $\langle\mathrm{TSN}\rangle$ sign group, Orkun also transcribes it as tašïn, but he translates it with the instrumental case as 'by stone(s)'. Orkun's translation is the same as

\footnotetext{
${ }^{2}$ The original translation of the Tunuquq inscription made by Thomsen (1922) is Danish.
} 
Thomsen's in this respect. However, Orkun interprets the rest of the sentence quite differently from him: he separates the construction tutmï̌ täg biz into two parts, as tutmï̌ täg and biz, then he inserts a supposed verbal phrase, that is tehlikede ol- 'to be in danger', between these two parts and translates the whole sentence accordingly. Orkun's interpretation can be criticised as follows: (1) Since there is no noun meaning 'tehlike' [danger] (cf. Old Turkic ada tuda in Clauson 1972, p. 40) with the locative case and no verb meaning ol- 'to be, to become' (cf. Old Turkic bol- in Clauson 1972 , p. 331) with the future tense (which surfaces as $-D A c ̌ I$ or $-\check{c} I$ in Orkhon Turkic), Orkun seems to translate the sentence in a very free way. (2) The 1st person plural biz cannot belong to the supposed verbal phrase *'to be in danger'. (3) The postpositional phrase tutmïs täg cannot qualify the supposed verbal phrase * 'to be in danger'. (4) Since tutmï̌ täg is a postpositional phrase which includes an active participle, it cannot be translated with a passive participle as 'tutulmuş gibi' [as though having been captured].

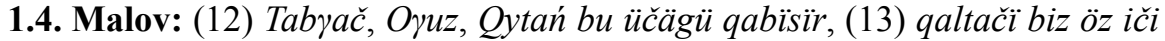
tasïn tutmïs täg biz (1951, p. 62) "Tabgači, Oguzy, Kidani, èti vtroem, esli soedinjatsja (ili: esli budut voevat' protiv nas), to my (požaluj) ostanemsja kak by predostavlennye samim sebe (ili: my ostanemsja, kak by derža svoju vnutrennost' vneš-

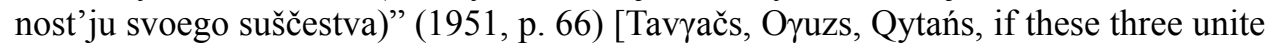
(or: if they fight against us), then we (perhaps) will remain as though having been left to ourselves (or: we will remain as though grasping our own interior with the exterior of our own being)].

Malov considers the 〈ẄzčI: TSN: TWTmstgbIz $\rangle$ sentence as a whole with the previous sentence, which starts with the word Tabyac in the 12th line and ends with qaltači biz at the beginning of the 13th line of the inscription. Malov transcribes $\langle$ TSN $\rangle$ as tasïn, but he translates it in a totally different way, as 'vnešnost'ju' [with the exterior of]. Accordingly, it is understood that Malov analyses the word tašin as taš $\ddot{\imath} \ddot{\imath}+n$ $<$ taš 'vnešnost" [exterior] $+\ddot{i}$ (3rd person singular possessive suffix) $+n$ (the instrumental case).

As for the sign group $\langle\ddot{W} z c ̌ I\rangle$, Malov reconstructs it as $\ddot{o z}[i] c ̌ i$ 'svoju vnutrennost" [(its) own interior (acc.)], probably based on the hendiadyoin ič taš 'the interior and exterior (of the tomb)' which is attested in Köl Tegin, Southern face, 12nd line $=$ Bilgä Qayan, Northern face, 14th line (see ič in Clauson 1972, p. 17a-b). This reconstruction of Malov was adopted by many subsequent researchers and the sign group $\langle\ddot{W} z c ̌ I\rangle$ was mostly read as * öz [i] či thereafter. However, this is not a proper solution, since the reading $* \ddot{o} z[i] c \check{c} i$ seems not to produce a proper meaning in the context. Furthermore, it is possible to read the sign group without adding a sign to it in the middle, as can be seen in the following section.

Another problem with Malov's interpretation lies in his alternative translation, given in parantheses. When this alternative translation is examined, it is understood that he considers $\ddot{o z}[i] \breve{c} i$ tašin tutmïs täg part of the mentioned sentence as a supposed postpositional phrase and evaluates it as the qualifier of the predicate qaltaci biz: qaltači biz öz [i]či tasïn tutmïs täg 'ili: my ostanemsja, kak by derža svoju vnutrennost' vnešnost'ju svoego suščestva' [or: we will remain, as though, grasping our 
own interior with the exterior of our own being]. However, it should be noted that the

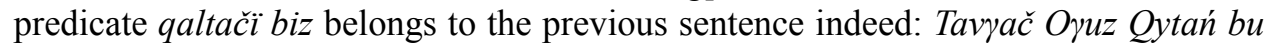
üčägü qavïssar qaltači biz | öz iči tasïn tutmïs täg biz.

In Malov's above-mentioned translation, the 1st person plural biz which follows the postposition täg is included neither in the sentence öz [i]či tasïn tutmïs täg biz, nor in the following sentence starting with yuyqa ärkli. In other words, Malov completely ignores the existence of the second biz which is inscribed between tutmïs täg and yuyqa ärkli. This misinterpretation of Malov stems from the fact that he could not discern the border of the sentences correctly.

1.5. Aalto-Ramstedt-Granö: özčä tašin tutmiš täg biz (1958, p. 35) "Bis ins Innere werden wir von aussen her gefasst (?) werden" (1958, p. 34) [We will be caught from the outside to the inside].

What is different in this study is that the first group of signs is transcribed as * özčä, since the last sign was read as * $\langle\mathrm{A}\rangle$, instead of $\langle\mathrm{I}\rangle$, by some researchers (Tekin 1994, p. 34). However, as can be seen in the photograph below, 〈ẄzčI $\rangle$ (and not

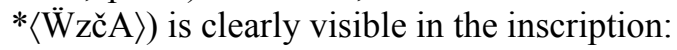

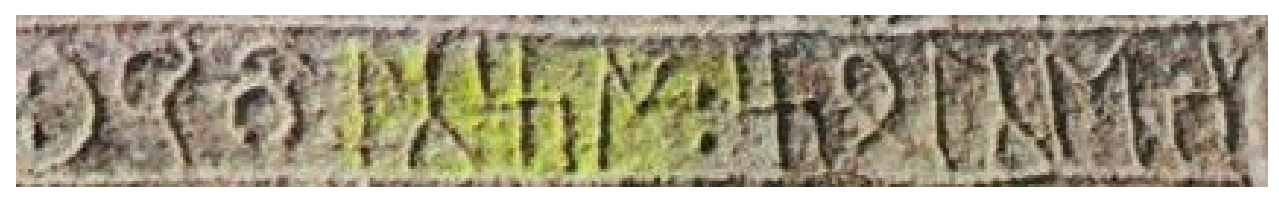

A partial appearance of the photograph no. 284, given in Alyılmaz 2005, p. 199.

In Aalto - Ramstedt-Granö's study, the sign group $\langle\ddot{W} z c ̌ I\rangle$, which was misinterpreted as * $\ddot{z} z \ddot{c} \ddot{a}$, is translated as 'bis ins Innere' [to the inside]. This reading is both semantically and grammatically improbable, because the Old Turkic lexeme $\ddot{z} z$ does not mean 'inside, inner, interior, internal' (the opposite of the lexeme taš 'outside, outer, exterior'). Moreover, the equative suffix $+\check{c} A$ does not function as the directive case suffix (see Erdal 2004, p. 376) in Old Turkic.

As for the signs $\langle\mathrm{TSN}\rangle$, Aalto-Ramstedt-Granö transcribe and translate it as tašin 'von außen her [from the outside]'. Nevertheless, the meaning 'from the outside' would supposedly be rendered by taštïn, not * tašin in Old Turkic. Other problematic issues in this study are that: (1) The postpositional phrase tutmïs täg, which includes an active participle, is translated with a passive clause as 'gefasst (?) werden [will be caught]'. (2) The postposition täg is excluded from the translation. (3) The predicative of the sentence is given in the future tense.

1.6. Giraud: üzči tašïn tutmïš täg biz (1961, p. 54) "Ils nous briseront. Nous serons comme lapidés"3 (1961, p. 60) [They will destroy us. We will be as though having been stoned].

${ }^{3}$ I would like to express my sincere thanks to Assistant Professor Hülya Bayrak Akyıldız from Anadolu University, Turkish Language and Literature Department, who helped me correctly interpret the French translation of the sentence. 
Giraud's interpretation is quite different from the previous researchers. Giraud

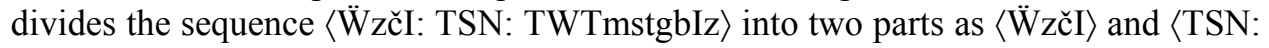
TWTmstgbIz $\rangle$ and makes his interpretations accordingly. He transcribes and translates $\langle\ddot{W} z c ̌ I\rangle$ as *üzči 'ils nous briseront' [they will destroy us] and considers this proposed lexeme as the predicate of a separate sentence whose personal pronoun is omitted. He analyses this proposed predicate as * $\ddot{u} z$ - $\check{c} i<\ddot{u} z$ - 'briser [to destroy]' (see Old Turkic $\ddot{u} z$ - in Clauson 1972, p. 279b), -či (the future tense 3rd person plural), which is semantically improbable in the context. This misinterpretation of Giraud stems from the fact that he could not discern the border of the sentences correctly.

Tašin tutmï̌ täg biz, the parts of the sentence that follow * üzči, is translated as 'Nous serons comme lapidés' [We will be as though having been stoned.] According to this interpretation, the suffixes added to the lexeme tas is not translated properly, and a verb such as bol- 'to be' and a future tense suffix are lacking in the mentioned sentence. Furthermore, the lexeme which gives the meaning 'to be stoned' would supposedly be *tašlan- < cf. tašla- II (Clauson 1972, p. 564b), not *tašin tut- in Old Turkic.

1.7. Tekin: öz [i]či tašïn tutmiš täg biz (1994, p. 7) "Kendi iç (kuvvetler)i (ile) dış (topraklar)1 tutmuş gibiyiz" (1994, p. 6) [We look as though we have held the external (lands) with its own internal (forces)].

Tekin was the first researcher who adopted Malov's (1951) * öz [i]či reconstruction. He stated (1994, p. 34) that since $\langle\mathrm{I}\rangle$ was not inscribed between $\langle\mathrm{z}\rangle$ and $\langle\check{\mathrm{c}}\rangle$ in the mentioned line, the previous researchers had misread the two words having been inscribed adjacently. In Tekin's study, $\langle\mathrm{TSN}\rangle$ is transcribed and translated as tašïn 'dış (topraklar)1' [external (lands) + acc.]. However, it should be noted that if $\langle\mathrm{TSN}\rangle$ were transcribed as tašïn, then the 3rd singular/plural possesive suffix (see above) should be included in the translation, since the accusative $+n$ must be preceded by the possessive paradigm in Orkhon Turkic. In that case, tašin should be translated not as 'dış (topraklar) +1 ' [external (lands) + acc.], but as 'dış (topraklar) $+1+n$ ' [his/their external (lands) + acc.]. As for $\langle$ TWTmstgbIz $\rangle$, Tekin is the first researcher who translates the phrase tutmiš täg biz as 'tutmuş gibiyiz' [We look as if we have held...], which is grammatically and semantically correct.

1.8. Rybatzki: özčä tašin tutmïs täg biz (1997, p. 50) “...[und] wir werden umkreist sein" (1997, p. 95) [...(and) we will be encircled].

Despite the mentioned sentence being freely translated as above, it is stated in the related footnote that it literally means "Wie selbst die eigene Außenseite haltend [werden] wir [sein]" = "We are [will be] as if we ourselves have held ${ }^{4}$ our own exterior". Here Rybatzki seemingly adopts Aalto-Ramstedt-Granö’s erroneous *özčä transcription and interprets this supposed lexeme as 'selbst' [self] in his literal translation. Consequently, it is understood that he analyses the supposed lexeme * $\ddot{z} z \check{c} \ddot{a}$ as $<\ddot{o z}$ (reflexive pronoun) $+\check{c} \ddot{a}$ (equative case suffix). However, since such a form as

\footnotetext{
${ }^{4}$ The word "haltend" in the German translation is actually a present participle. The reason why Rybatzki used a present participle here may be that Old Turkic past participle -mǐs cannot be translated by a past participle in German in the sentence structure above. Therefore, I made the English translation of the sentence by past participle as in the inscription.
} 
* özčä is not attested in Old or Modern Turkic languages, the literal translation of the mentioned sentence is semantically doubtful.

1.9. Berta: $\ddot{o z z}{ }^{\circ}$ či tašï tutmwš täg biz (2004, p. 51) "[Olyanok] leszünk mint az [aminek] saját belseje fogja meg a külsejét" $(2004$, p. 77) [We will be (such) that as if (its) own interior grasps the exterior].

As can be seen above, Berta marks a sound without certain value between $\langle\mathrm{z}\rangle$ and $\langle\check{c}\rangle$ regarding the sign group $\langle\ddot{W} z \check{c} I\rangle$. Since his 'saját belseje' [own interior] translation is equivalent to that supposed Old Turkic phrase * $\ddot{o z}[i] c \check{i}$, it is understood that he considers that sound without certain value to be $\langle\mathrm{I}\rangle$ as Malov did. Berta transcribes $\langle\mathrm{TSN}\rangle$ as tašin 'a külsejét' [its exterior (in accusative)], again following in the footsteps of Malov. However, it should be noted that Berta's translation stands closer to that of Tekin rather than to that of Malov's. Finally, as for the predicative of the sentence, Berta translates it in the future tense, as most of his predecessors did. But as stated above, it is grammatically not correct.

1.10. ÖImez: öz iči tašin tutmïs täg biz (2012, p. 164) "Biz kendi kendimizi kapana kıstırmış gibiyiz" (2012, p. 17) [We look as if we have trapped ourselves].

Ölmez's transcription is the same as Malov's (1951), Tekin's (1994) and Berta's (2004). As can be seen above, he translates the sentence freely. In terms of meaning, this free translation seems to fit the context in which the sentence occurs. Still, as discussed above, the reading *[i] $c i$ is unacceptable since it is orthographically not supportable.

1.11. Aydın: özčä tašïn tutmï̌ täg biz "Kendimizce dışarıyı tutmuş gibiyiz [We ourselves look, as it were, to have kept the outside]" (2014, p. 118).

Like Rybatzki, Aydın also adopts Aalto-Ramstedt-Granö's (1958) erroneous

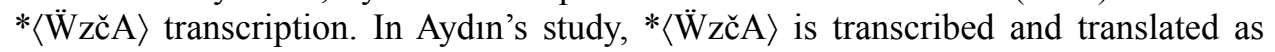
* $\ddot{z} z \check{a} \ddot{a}$ 'kendimiz+ce' [ourselves + the equative case suffix]. But as stated above, the equative case suffix $+\check{c} A$ added to the reflexive pronoun $\ddot{o z}$ is grammatically incorrect (see section 1.8 above). Besides, in case the sign group $\langle\mathrm{TSN}\rangle$ is transcribed and analysed as $\operatorname{tašin}<\operatorname{tas}+\ddot{i}+n$, this reading should be interpreted not as *'dışarıyı' [outside + acc.], but 'dışını' [its outside + acc.].

\section{Proposal for a New Reading and Interpretation}

Although the readings and interpretations of the sentence 〈ẄzčI: TSN: TWTmstgbIz〉 are quite different from one another, there is one common point: the sign group $\langle\mathrm{TSN}\rangle$ is transcribed with $\check{s}$ as tašïn. However, we must bear in mind that there is no separate sign for $\breve{s}$ in the Tunuquq inscription. In this inscription, the front $s$ mark is also used for the front $\breve{s}$, and the back $s$ mark is used for the back $\breve{s}$ (Tekin 1994, p. IX). In this case, it is also possible to transcribe the sign $\langle\mathrm{S}\rangle$ in the $\langle\mathrm{TSN}\rangle$ sequence with the back $s$, not with the back $\check{s}$.

There is one more part of the interpretation proposals which the majority of the researchers share: it is the supposition that the sign $*\langle\mathrm{I}\rangle$ should have been inscribed

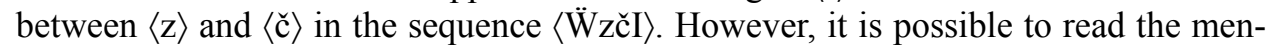


tioned sentence in a different way without inserting an $*\langle\mathrm{I}\rangle$ between $\langle\mathrm{z}\rangle$ and $\langle\check{\mathrm{c}}\rangle$ and transcribing the sign $\langle\mathrm{S}\rangle$ not as $\check{S}$ but as $s$, as below:

\section{Öz äči atïsïn tutmïs täg biz}

"We look as if (someone's) own (paternal) uncle ${ }^{5}$ have captured his own nephew".

It is certain that the context is of great importance in interpreting the mentioned sentence in this way. This sentence occurs in a context in which Bilgä Tunuquq reports one of his official conversations with his Qayan:

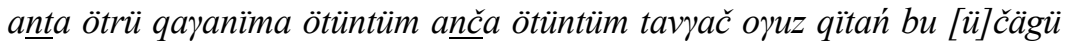

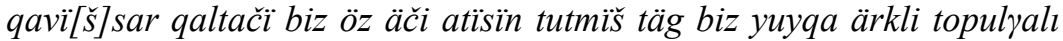
učuz ärmiš yinčgä ärklig üzgäli učuz yuyqa qalïn bolsar topulyuluq alp

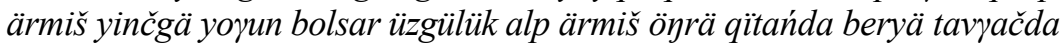

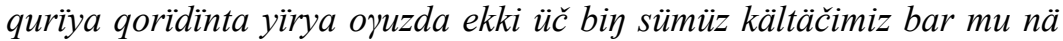
anča ötüntüm

"Then I made representations to my khagan; this is what I represented: 'China, Oghuz and Qytań, if these three assemble, we will fail to operate. We look as if (someone's) own (paternal) uncle have captured his own nephew. That which is flimsy is easy to pierce, that which is thin is easy to tear. (But) when the flimsy thing becomes thicker, it is difficult to pierce it, when the thin thing becomes thicker, it is difficult to tear it. I wonder if we have two or three thousand soldiers who will arrive from the Qytań in the east, from the Chinese in the south, from the Qory in the west, from the Oghuz in the north?' This is what I represented."

As can be seen here, Bilgä Tuńuquq warns his Qayan against the danger from China, Qytań and Oghuz in the sentence starting with Tavyač and ending with qaltači biz. He warns that they will fail to operate in case these three forces assemble. The following sentence is the one which is evaluated in the study at hand and it explains why they will fail to operate against the assembled forces. The reason may be that the people which are supposed to be in alliance have been in internal disorder ${ }^{6}$. This state of internal disorder is compared by Bilgä Tunuquq, who presents inventive analogies elsewhere in the inscription, with the image that a paternal uncle battles against his own nephew and finally captures him. This interpretation is consistent with the logical flow of the context, since the following sentence emphasises the importance of being together as a solution.

${ }^{5}$ As a matter of fact, the word $\ddot{a c} i$ means 'a close male relative younger than one's father and older than oneself', i.e. both '(junior) paternal uncle' or 'elder brother' (see eči I in Clauson 1972, p. 20a). Since the word äči is used in the related sentence beside atï '(junior) nephew' or 'grandson' (Clauson 1972, p. 40b), it would be better to interpret the word äči as '(paternal) uncle' in the given context.

${ }^{6}$ Similar situations of disorder or conflict are described elsewhere in the Orkhon Inscriptions, cf. Köl Tegin, Eastern face, 6th line and Tunuquq, 22nd line. 
Finally, the reason why Bilgä Tuńuquq chooses the words $\ddot{a} c i$ and at $\ddot{i}$ for the analogy in line 13 is not coincidental, but stems from a social reality. This reality is that the guardianship of a deceased father's children is undertaken by a paternal relative, especially by an uncle or an elder brother in ancient Turkic societies (Bazin 2011, p. 108). Therefore, an uncle-nephew relationship may be considered as nearly equal to a father-son relationship in those societies. So, by drawing an analogy between a conflicting uncle-nephew relationship and the people in disorder, Bilgä Tunuquq strikingly expresses the state in which they were. Then he completes his words by giving the message of unity at the end of the related passage of the inscription.

\section{Conclusion}

In this study, the problematic issues in the sentence $\langle$ ẄzčI : TSN : TWTmstgbIz of the 13th line of the Tunuquq inscription were treated in detail from the vantage point of orthography, grammatical structure and semantics of Old Turkic words. Here, the sequence $\langle\ddot{W} z c ̌ I\rangle$ was interpreted without inserting any sign between $\langle z\rangle$ and $\langle\breve{c}\rangle$ as $\ddot{o r z}$ $\ddot{a c} i$ ' (someone's) own (paternal) uncle'. Besides, the sign group $\langle\mathrm{TSN}\rangle$ in the mentioned line was read as atïsin 'his nephew (acc.)'. In addition, the meaning 'to capture' of the Old Turkic verb tut- was emphasised in the interpretation. Accordingly, the whole sentence was translated as öz äči atïsïn tutmïs täg biz 'We look, as it were, (someone's) own (paternal) uncle have captured his own nephew'. This new reading proposal provides a reasonable alternative to the former readings which did not make any sense in the given context of the inscription.

\section{References}

Aalto, P.-Ramstedt, G. J.-Granö, J. G. (1958): Materialien zu den alttürkischen Inschriften der Mongolei. Helsinki, Suomalais-Ugrilainen Seura.

Alyılmaz, Cengiz (2005): Orhun Yazıtlarının Bugünkü Durumu. Ankara, Kurmay.

Aydın, Erhan (2014): Orhon Yazıtları (Köl Tegin, Bilge Kă̆an, Tonyukuk, Ongi, Küli Çor). Konya, Kömen, 2nd ed.

Bazin, Louis (2011): Eski Türk Dünyasında Kronoloji Yöntemleri (trans. by Vedat Köken). Ankara, TDK Yayınları.

Berta, Árpád (2004): Szavaimat jól halljátok... A türk és ujgur rovásírásos emlékek kritikai kiadása [Closely listen to my words ... A critical editon of records in Turkic and Uyghur runic scripts]. Szeged, Jatepress.

Berta, Árpád (2010): Sözlerimi İyi Dinleyin... Türk ve Runik Uygur Yazıtlarının Karşılaştırmalı Yayını. (trans. Emine Yılmaz). Ankara, Türk Dil Kurumu Yayınları.

Clauson, Gerard (1972): An Etymological Dictionary of Pre-Thirteenth-Century Turkish. Oxford, Clarendon.

Erdal, Marcel (2004): A Grammar of Old Turkic. Leiden-Boston, Brill.

Giraud, René (1961): L'inscription de Baïn Tsokto. Paris, Librairie d'Amérique et d'Orient.

Kormušin, Igor (2007): Semiz Buka Turuk Buka Teyin Bilmez Ermiş' Sözünde Tonyukuk Kimi ve Neyi Kastetmiştir? In: Aydın, Gülzemin Özrenk (ed.): 46. Uluslararası Sürekli Altaistik 
Konferansı Bildirileri: Altay Dünyasında Gündelik Hayat. Ankara, Türk Dil Kurumu, pp. $263-269$.

Malov, S. E. (1951): Pamjatniki drevnetjurkskoj pis'mennosti. Moscow-Leningrad, Akademija Nauk.

Orkun, Hüseyin Namık (1936): Eski Türk Yazıtları I. İstanbul, Türk Dil Kurumu Devlet Basımevi.

Ölmez, Mehmet (2012): Moğolistan'daki Eski Türk Yazıtlart. Ankara, Bilgesu.

Radloff, Wilhelm (1899): Die altü̈rkischen Inschriften der Mongolei (Zweite Folge). St. Petersburg.

Rybatzki, Volker (1997): Die Toñukuk Inschrift. Szeged (Studia Uralo-Altaica 40).

Tekin, Talat (1994): Tunyukuk Yazıtı. Ankara (Türk Dilleri Araştırmaları Dizisi 5).

Tekin, Talat (2006): Orhon Yazıtları. Ankara, Türk Dil Kurumu Yayınları.

Tezcan, Semih (1976): Tonyukuk Yazıtında Birkaç Düzeltme. Türk Dilleri Araştırmaları Yıllığı Belleten 1975-1976, pp. 173-181.

Tezcan, Semih (2010): Yazıtlarda Yeni Okuyuş ve Anlamlandırma Önerileri. In: Alyılmaz, Cengiz-Ay, Özgür-Yılmaz, Metin (eds): I. Uluslararası Uzak Asya'dan Ön Asya'ya Eski Türkçe Bilgi Şöleni Bildirileri. Afyon, Afyon Kocatepe Üniversitesi \&Türk Dil Kurumu, pp. $273-280$.

Thomsen, W. (1922): Samlede Afhandlinger III. Kopenhagen, pp. 465-516.

Thomsen, W. (1924): Alttürkische Inschriften aus der Mongolei in Übersetzung und mit Einleitung (trans. Hans Heinrich Schaeder). ZDMG Vol. 78, 1924/1925, pp. 121-175. 